\title{
White-tailed deer use of rangeland following browse rejuvenation
}

\author{
JOSEPH A. BOZZO, SAMUEL L. BEASOM, AND TIMOTHY E. FULBRIGHT
}

Authors are graduate research fellow, director, and professor, Caesar Kleberg Wildlife Research Institute, Campus Box 218, Texas A\&I University, Kingsville 78363.

\begin{abstract}
Mechanical top growth removal of certain shrub species stimulates sprouting and temporarily increases nutritional quality, availability, and yield of browse. We determined the effects of (1) roller chopping separate portions of rangeland, dominated by guajillo (Acacia berlandieri Benth.) and blackbrush acacia ( $A$. rigidula Benth.), during consecutive years and (2) disking separate portions of rangeland, dominated by dense whitebrush (Aloysia lyciodes Cham.) thickets, during consecutive years on white-tailed deer (Odocoileus virginianus Raf.) use of the treated areas. Separate, adjacent portions of guajillo and blackbrush acacia-dominated rangeland were roller chopped in a pattern of alternating treated and untreated strips each year during summer for 4 consecutive years (1985-1988) on an area in Duval County, Tex., and for 2 years (1988-1989) on areas in Duval and McMullen counties, Texas. Whitebrush-dominated rangeland was disced in a similar pattern during 2 years (1988-1989). Twenty percent of each study site was treated each year. Estimated deer density in the rollerchopped area in Duval County was higher than estimated deer density in an untreated area during 1985-1987 and in 1989. Roller chopping in study areas in Duval and McMullen counties increased deer fecal pellet-group densities (groups $\mathrm{ha}^{-1}$ day $^{-1}$ ) relative to untreated sites in winter, spring, and summer 1989 and when averaged over the 21 -month study. Discing dense whitebrushdominated sites increased pellet-group densities relative to untreated sites in spring and summer 1989 and when averaged across the 21-month study period. Increased deer use of treated areas was probably a function of several factors, including increased forb availability and increased nighttime visibility for predator detection.
\end{abstract}

Key Words: disc, habitat management, Odocoileus virginianus, roller chopper

Browse rejuvention, or top growth removal of woody plants to stimulate sprouting, temporarily increases nutritional quality, availability, and yield of browse (Scotter 1980, Vallentine 1980, Yoakum et al. 1980). Habitats in which the practice has been applied include chaparral vegetation in California (Yoakum et al. 1980), stands of bitterbrush [Purshia tridentata Pursh (DC.)], gambel oak (Quercus gambelii Nutt.), curlleaf mountain mahogany (Cercocapus ledifolius Nutt.) (Vallentine 1980), and stands of mixed brush in southern Texas (Powell and Box 1966, Everitt 1983, Fulbright et al. 1991).

Drawe (1981) postulated that mechanical top growth removal on a portion of the range each year would provide a continuing supply of nutritious, readily available browse. Nutritional quality of south Texas shrubs following top growth removal remains elevated for 2 to 13 months posttreatment (Everitt 1983, Asah and

\footnotetext{
Research was funded by the Enron Corporation and the J.F. Welder Heirs. The authors wish to thank Tom Martin, Jr., for providing the research area. J.P. Reynolds assisted in collection and analyses of data from the Esperanza Ranch.

Manuscript accepted 22 Feb. 1992.
}

Fulbright 1987, Fulbright et al. 1991).

Nutritional value of shrubs browsed by white-tailed deer ( Odocoileus virginianus $\mathrm{Raf}$.) in southern Texas is lowest in the summer (Barnes et al. 1991) and may limit deer populations (Meyer et al. 1984). Deer are primarily browsers during late summer and early fall, whereas forbs constitute the bulk of diets during late winter, spring, and early summer. Timing browse rejuvenation during summer may improve browse nutritional quality during this critical period (Everitt 1983). One of our objectives was to determine the effects of roller chopping separate portions of rangeland dominated by guajillo (Acacia berlandieri Benth.) and blackbrush acacia ( $A$. rigidula Benth.) in summer during consecutive years on white-tailed deer use of the treated areas. We applied a similar brush management strategy on rangeland dominated by whitebrush (Aloysia lyciodes Cham.), which forms dense thickets on fertile lowland areas and is of low browse value for deer (Scifres 1980). Heavy disking reduces canopy cover of the shallow-rooted shrub, but stimulates regrowth of more deeply rooted shrubs such as spiny hackberry (Celtis pallida Torr.) that are of high browse value (Bozzo et al. 1992). Our second objective was to determine the effects of consecutive yearly disking of separate portions of rangeland dominated by dense whitebrush thickets on white-tailed deer use of treated areas. Vegetation responses to these treatments are reported in Bozzo et al. (1992).

\section{Methods}

\section{Study Areas}

The study was conducted on the 7,285-ha Esperanza Ranch in Duval County, Tex., and the 4,800-ha La Campana Ranch in McMullen and Duval counties, Tex. Climate, soils, and vegetation of the Esperanza and La Campana ranches are described in Fulbright et al. (1991) and Bozzo et al. (1992), respectively.

Both ranches were continuously grazed by cattle. Cattle stocking rates on the Esperanza Ranch ranged from 0.03 to 0.15 animal units ha ${ }^{-1}$ year $^{-1}$ (M. Barrett, Esperanza Ranch, pers. commun.). Cattle stocking on the La Campana Ranch also varied, but averaged 0.08 animal units ha $^{-1}$ year $^{-1}$ (J. Locke, La Campana Ranch, pers. commun.). Cattle use of study sites on the La Campana Ranch was infrequent.

\section{Esperanza Ranch}

Parallel strips of brush $40 \mathrm{~m}$ wide and $1.2-1.8 \mathrm{~km}$ long were roller chopped annually in a 405-ha study area on the Esperanza Ranch using a 6.4-m-wide (about $27,300 \mathrm{~kg}$ ) roller chopper pulled by a crawler tractor in a pattern of alternating roller-chopped and untreated strips during the summers of 1985-1988. About $20 \%$ of the area was roller chopped annually, resulting in a repeating series of sequentially roller-chopped strips, with strips roller chopped each year adjacent to each other and each series adjacent to untreated brush. This provided brush regrowth of varying ages and sizes. An area of similar size about $2.3 \mathrm{~km}$ distant was selected for a control. Licht (1987) reported that white-tailed deer on the 


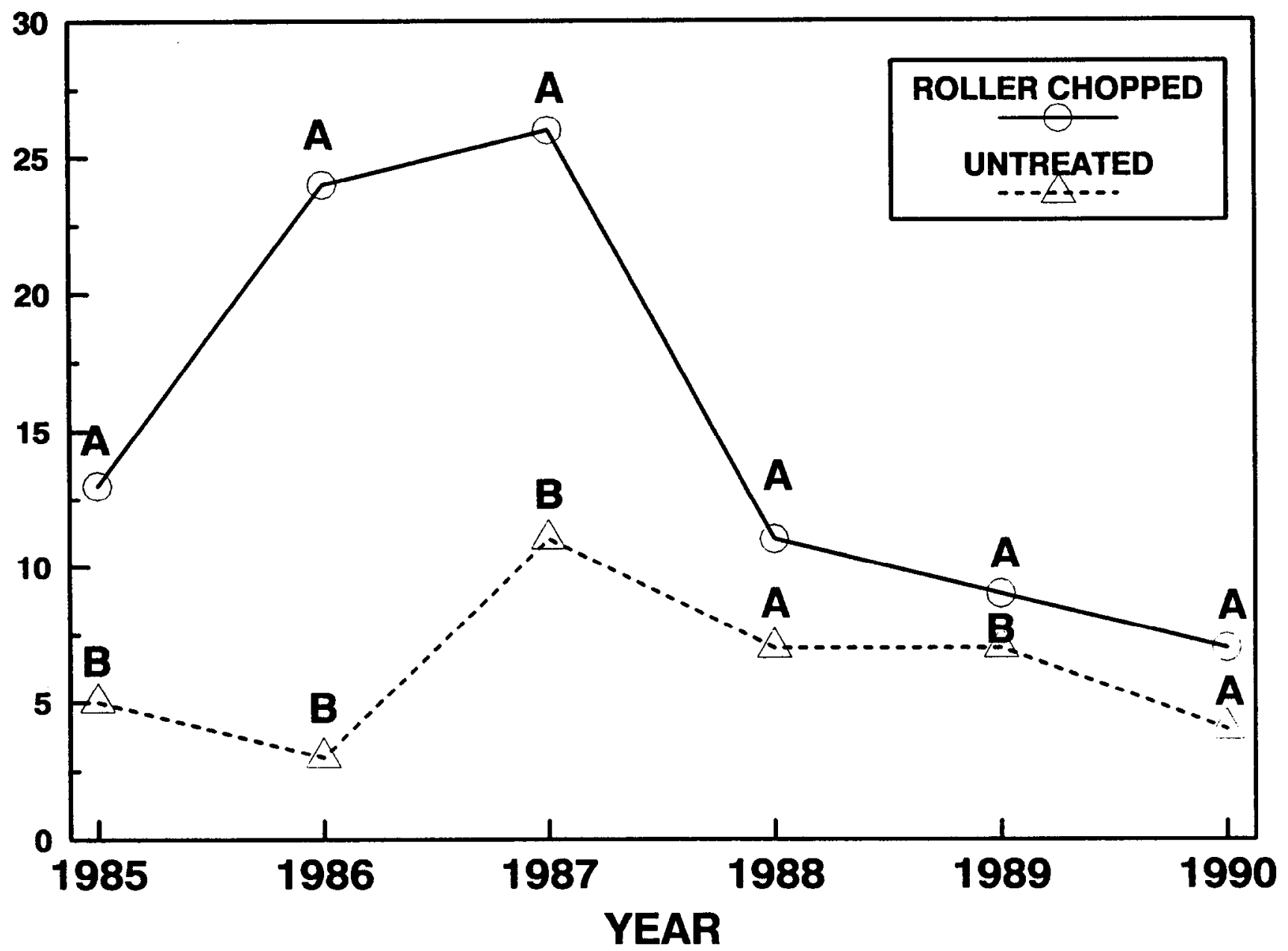

Fig. 1. Temporal trends in white-tailed deer density in a roller-chopped area and in an untreated area according to helicopter counts ( $n=8$ transects $/$ area) during October 1985-1990, Duval County, Tex. Pairs of means within a year associated with the same letter are similar $(P>0.05)$.

Edwards Plateau of central Texas rarely travel farther than $2 \mathrm{~km}$ from the center of their home range, and home range sizes average only $1.0 \mathrm{~km}^{2}$ for does and $4.2 \mathrm{~km}^{2}$ for bucks. Ellisor (1969) and Inglis et al. (1986) reported home ranges of deer on the Rio Grande Plains in Dimmit County, Tex., to be $2.4 \mathrm{~km}^{2}$ and $1.9 \mathrm{~km}^{2}$, respectively. Thus, samples between sites were assumed independent.

Annual helicopter surveys were conducted during October from 1985 to 1990 to estimate density of deer in the treated and control areas. Eight transects ranging from 1.2 to $2.0-\mathrm{km}$ long and $200-\mathrm{m}$ wide were flown in the treated and control areas at a speed of 40-56 $\mathrm{km}$ hour $^{-1}$ and an altitude of $15-18 \mathrm{~m}$. Two observers counted deer on their respective side of the transect midline. Transects were flown for complete coverage. In 1990, we determined effective strip width in the 2 areas using methods of DeYoung et al. (1989). The effective strip width was similar between the control (correction factor $=3.40$ ) and treated (correction factor $=3.38$ ) areas.

Data were analyzed using $t$-tests (Steel and Torrie 1980). The experiment was not replicated because of the expense of the treatments. Because the experiment was not replicated, treatment effects were possibly confounded with site effects. Statistical inference is valid when treatments are not replicated, but inferences pertain only to specific sites (Steel and Torrie 1980, Hurlbert 1984).

\section{La Campana Ranch}

A second experiment was conducted on the La Campana Ranch to provide a replicated test of the effects of roller chopping guajilloblackbrush acacia-dominated sites on deer use. Roller-chopping treatments were applied to 3 separate dense guajillo-blackbrush acacia-dominated sites, ranging from 30 to 125 ha in size, during
July 1988. Initial treatment consisted of $61-\mathrm{m}$-wide treated strips alternating with adjacent $244-m$-wide untreated strips. This resulted in about $20 \%$ of each site receiving treatment. Additional $61-\mathrm{m}-$ wide treated strips were placed adjacent to the initial treated strips during June 1989. Three separate sites with similar vegetation were selected as experimental controls.

Three separate dense whitebrush-dominated sites on the La Campana Ranch ranging from 16 to 41 ha in size received heavy discing treatments during July 1988 . Initial treatment consisted of a 55-m-wide single-treatment strip applied in an oval or horseshoe pattern using a 3.7-m-wide Steiger disc with 91-cm blades. An additional 55-m-wide strip was disced adjacent to each initially treated strip in May 1989. Three similar sites were used as controls. All treated and control sites were $>1.6 \mathrm{~km}$ apart.

Percent brush canopy cover, estimated using the line-intercept method (Canfield 1941), was used to determine similarities between sites. Twenty $15-\mathrm{m}$ line transects were randomly located in untreated sites and in treated sites. In treated sites, 10 transects were randomly located in the untreated portions and 10 in treated portions. Line transects were placed using a stratified random sampling method (Knight 1978: in Chambers and Brown 1983) and were measured on a seasonal basis (winter = January-March, spring = April-June, summer = July-September, and fall = October-December). Percent canopy coverage of herbaceous plants was estimated in $20 \times 50-\mathrm{cm}$ quadrats placed at 5-m intervals along each transect (Bonham 1989). Canopy cover was estimated in 60 quadrats per site. Percent similarity between sites was determined using Sorenson's community coefficient quantitatively modified (Motyka et al. 1950: in Meuller-Dombois and Ellenberg 1974). 
Table 1. Mean pellet group density for 3 disced (D) and 3 untreated (U) dense whitebrush sites and 3 roller-chopped (RC) and 3 untreated (U) dense guajillo-blackbrush acacia sites on the La Campana Ranch, McMullen and Duval counties, Tex., summer 1988-spring 1990.

\begin{tabular}{|c|c|c|c|c|c|c|c|c|}
\hline \multirow[b]{3}{*}{ Season } & \multicolumn{4}{|c|}{ Whitebrush } & \multicolumn{4}{|c|}{ Guajillo-blackbrush acacia } \\
\hline & \multicolumn{2}{|c|}{ D } & \multicolumn{2}{|c|}{$\mathrm{U}$} & \multicolumn{2}{|c|}{ RC } & \multicolumn{2}{|c|}{$\mathrm{U}$} \\
\hline & $\bar{x}$ & SD & $\bar{x}$ & SD & $\bar{x}$ & SD & $\overline{\boldsymbol{x}}$ & SD \\
\hline & \multicolumn{8}{|c|}{ 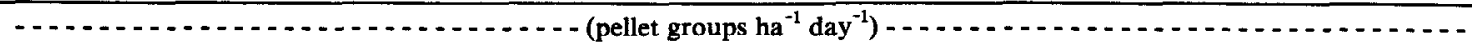 } \\
\hline Summer 1988 & 0.29 & 0.05 & 0.15 & 0.15 & 0.43 & 0.15 & 0.31 & 0.11 \\
\hline Fall 1988 & 0.36 & 0.34 & 0.17 & 0.17 & 0.34 & 0.32 & 0.12 & 0.04 \\
\hline Winter 1989 & 1.63 & 0.95 & 0.90 & 0.45 & 1.32 & 0.71 & $0.08^{*}$ & 0.08 \\
\hline Spring 1989 & 1.43 & 0.45 & $0.27^{*}$ & 0.40 & 1.17 & 0.34 & $0.27^{*}$ & 0.22 \\
\hline Summer 1989 & 1.15 & 0.33 & $0.31^{*}$ & 0.25 & 1.25 & 0.46 & $0.06^{*}$ & 0.02 \\
\hline Fall 1989 & 0.41 & 0.06 & 0.18 & 0.18 & 0.85 & 0.85 & 0.03 & 0.02 \\
\hline Winter 1990 & 0.70 & 0.26 & 0.74 & 1.05 & 2.06 & 1.32 & 0.14 & 0.09 \\
\hline Spring 1990 & 0.26 & 0.16 & 0.00 & 0.00 & 0.72 & 0.64 & 0.21 & 0.25 \\
\hline
\end{tabular}

*Significant at the 0.05 level.

Averaged across all sampling dates, mean plant community similarity between untreated portions of roller-chopped guajillo and blackbrush acacia-dominated sites and untreated sites was $80 \%$, and similarity between untreated portions of disced sites and untreated whitebrush-dominated sites was $82 \%$.

The estimated deer population on the ranch was $629\left(8.6 \mathrm{~km}^{-2}\right)$ in 1988 and $639\left(8.8 \mathrm{~km}^{-2}\right)$ in 1989 based on annual helicopter counts in October. Treated and control areas were too small to conduct accurate helicopter acounts specifically in them; therefore, we assessed trends in deer use by pellet-group counts. During JuneJuly 1988, 2 randomly selected, permanent line transects were established in each site to count deer fecal-pellet groups (Anderson et al. 1979). Each transect line ranged from 182 to $831 \mathrm{~m}$. Transect lines were established perpendicular to the treated strips in treated sites. Transects were walked once every 3 months to determine seasonal deer use. Perpendicular distance from the transect line to the midpoint of each deer pellet group seen was measured. A pellet group consisted of $>5$ pellets of similar shape, size, and color. Pellet groups were removed after being recorded to prevent recounting on subsequent surveys. An estimate of seasonal pelletgroup density was derived for each site using the Fourier series estimator (Burnham et al. 1980). Seasonal pellet-group densities for treated sites were combined and tested against seasonal pelletgroup densities of untreated sites using 2-sample $t$-tests $(n=3)$ to determine effects of treatment on deer use. Repeated measures analysis was used to test for treatment differences in pellet-group densities across seasons following the initial summer 1988 survey. Differences were considered significant at the 0.05 level.

\section{Results}

\section{Roller Chopping}

Estimated deer density in the roller-chopped area of the Esperanza Ranch was higher than estimated deer density in the control area during 1985-1987 and in 1989 (Fig. 1). On the La Campana Ranch, pellet-group density between roller-chopped $(0.43 \pm 0.15$ groups ha ${ }^{-1}$ day $\left.^{-1}\right)$ and untreated sites $\left(0.31 \pm 0.11\right.$ groups $\mathrm{ha}^{-1}$ day $^{-1}$ ) was similar for summer 1988, indicating that pretreatment use by deer was similar (Table 1). Pellet-group densities were greater in roller-chopped sites, compared with untreated sites, in winter, spring, and summer 1989, and when averaged across seasons following the initial survey. Within roller-chopped sites, $36.2 \%$ of pellet-groups found were in roller-chopped strips. Rollerchopped strips comprised $35.5 \%$ of total line transect length during the study.

Brush canopy cover of untreated portions of roller-chopped sites on the La Campana Ranch averaged 76.5 $\pm 4.1(\bar{x} \pm$ SD) across sampling dates, whereas that of untreated sites was $81.2 \pm 4.0 \%$. Grass and forb cover averaged $3.6 \pm 2.5 \%$ and $10.2 \pm 15.6 \%$, respectively, for roller-chopped residual sites, whereas untreated sites had $1.7 \pm 1.7 \%$ and $11.2 \pm 14.3 \%$, respectively.

\section{Discing}

Similarity in pellet-group densities between disced and untreated sites for summer 1988 suggests that deer use was similar before treatment (Table 1). Pellet-group densities were greater in disced sites compared with untreated sites in spring and summer 1989, and when averaged across seasons following the initial survey. Within disced sites, $43 \%$ of pellet groups found were in treated strips. Treated strips comprised $29 \%$ of total line transect length during the study, which suggests deer were attracted to the disced strips. Because defecation rates may change with season (Rogers 1987, Sawyer et al. 1990) differences among seasonal use of sites was not tested.

Canopy cover of brush, grass, and forbs over all seasons, for untreated portions of disced whitebrush sites was $76.5 \pm 6.3,10.1 \pm$ 5.1 , and $22.4 \pm 33.2 \%$, respectively. Untreated whitebrush sites had cover values for brush, grass, and forbs of 74.7 $\pm 2.8,16.2 \pm 7.8$, and $25.1 \pm 33.0 \%$, respectively.

\section{Discussion}

Roller chopping separate portions of rangeland dominated by guajillo and blackbrush acacia during consecutive years in early summer to rejuvenate browse increased deer use of the treated areas. Inglis et al. (1986) suggested that maximum deer densities could not be maintained following clearing $\geq 66 \%$ of rangeland in a strip pattern in the Texas Rio Grande Plains. Although $80 \%$ of the Esperanza Ranch area was roller-chopped, $20 \%$ of the area was treated each year over a 4-year period and brush canopy cover on treated strips increased rapidly following treatment (Bozzo et al. 1992). Thus, the treatment reduced brush cover much less than if $80 \%$ of the area had been treated at one time. A caveat regarding our results on the La Campana Ranch is that deer use as determined by fecal counts may be biased against feeding areas because animals defecate more when moving than when feeding (Severson and Medina 1983).

Although the objective of roller chopping was to increase nutritional quality and availability of browse, the amount of browse in deer diets on roller-chopped and untreated rangeland on the Esperanza Ranch was similar or greater on the untreated range (J.P. Reynolds, unpublished data). Forbs comprised more of deer diets in the roller-chopped area than in the untreated area during October 1986, but comprised a greater portion of deer diets in the untreated area in October 1987. Rollins et al. (1988) reported increased deer numbers (2-8 fold) following 50 and $70 \%$ (6-10 8.1-ha openings) chaining of live-oak (Quercus virginiana Mill.) dominated rangeland on the Edwards Plateau of Texas and attrib- 
uted increased densities to increased forb production. Pellet-group densities in guajillo-blackbrush acacia sites on the La Campana Ranch did not correspond with forb canopy cover on a seasonal basis. Significant increases in both pellet-group density and forb cover occurred concurrently in summer 1989 , whereas forbs in treated sites were also significantly increased in winter and spring 1990 (Bozzo et al. 1992). Lack of differences in pellet-group density during periods of high forb cover in roller-chopped sites may be attributed to deer diets. If deer consumed browse (higher in fiber) on untreated sites, then their defecation rates would be higher than deer feeding on preferred herbaceous material (Rogers 1987).

For whitebrush sites, increased forb cover on treated strips in spring and summer 1989 (Bozzo et al. 1992) may have influenced deer use during those seasons. Deer use of disced strips throughout the study was high. Although accessibility was probably increased, increased deer use of disced areas over the entire study was not related to increased total herbaceous cover, because herbaceous cover was similar (1988 treatment) or reduced (1989 treatment) overall.

Increased deer use of treated areas was probably a function of several factors including increased forb availability and increased nighttime visibility for predator detection (Inglis et al. 1986). Research on the relative importance of forb availability, browse availability and nutritional quality, and brush canopy cover and structural characteristics as mechanisms governing deer use of treated areas is needed for managers to devise brush management strategies that result in optimum deer habitat.

\section{Literature Cited}

Asah, H.A., T.E. Fulbright, and M.L. Land. 1987. Effects of simulated browsing on spiny hackberry after top removal. Texas J. Agr. and Natur. Res. 1:16-18.

Anderson, D.R., J.L. Laake, B.R. Crain, and K.P. Burnham. 1979. Guidelines for line transect sampling of biological populations. J. Wildl. Manage. 43:70-78.

Barnes, T.G., L.H. Blankenship, L.W. Varner, and J.F. Gallagher. 1991. Digestibility of guajillo for white-tailed deer. J. Range Manage. 44:606610 .

Bonham, C.D. 1989. Measurements for terrestrial vegetation. John Wiley and Sons, N.Y.

Bozzo, J.A., S.L. Beasom, and T.E. Fulbright. 1992. Vegetation responses to 2 brush management practices in south Texas. J. Range Manage. 45:In Press.

Burnham, K.P., D.R. Anderson, and J.L. Laake. 1980. Estimation of density from line transect sampling of biological populations. Wildl. Monogr. 72:1-202.

Canfield, R. 1941. Application of line interception in sampling range vegetation. J. Forest. 39:388-394.
Chambers, J.C., and R.W. Brown. 1983. Methods for vegetation sampling and analysis on revegetated mined lanes. Gen. Tech. Rep. INT-151. USDA Forest Serv., Intermountain Forest and Range Exp. Sta. Ogden, $\mathrm{Ut}$.

DeYoung, C.A., F.S. Guthery, S.L. Beasom, S.P. Coughlin, and J.R. Heffelfinger. 1989. Improving estimates of white-tailed deer abundance from helicopter surveys. Wildl. Soc. Bull. 17:275-279.

Drawe, D.L. 1981. Wild life responses to range management practices: the Welder Wildlife Refuge Experience-implications for the future, p. 86-92. In: Beef Cattle Sci. Handbk. Vol. 18. Int. Stockman's School.

Ellisor, J.E. 1969. Mobility of white-tailed deer in south Texas. J. Wildl. Manage. 33:220-222.

Everitt, J.H. 1983. Effects of shredding on nutrient content of four south Texas deer browse species. J. Range Manage. 36:779-781.

Fulbright, T.E., J.P. Reynolds, S.L. Beasom, and S. Demarais. 1991. Mineral content of guajillo regrowth following roller chopping. J. Range Manage. 44:520-522.

Hurlbert, S.H. 1984. Pseudoreplication and the design of ecological field experiments. Ecol. Monogr. 54:187-211.

Inglis, J.M., B.A. Brown, C.A. McMahan, and R.E. Hood. 1986. Deer brush relationships on the Rio Grande Plain, Texas. Caesar Kleberg Res. Program in Wildl. Ecol., Tex. Agr. Exp. Sta. Contr. TA16129. Tex. A\&M Univ., College Station.

Licht, D.S. 1987. Movement of white-tailed deer in the Edwards Plateau region and responses to point attractants. M.S. Thesis, Tex. A\&M Univ., College Station.

Meuller-Dombois, D., and H. Ellenberg. 1974. Aims and methods of vegetation ecology. John Wiley \& Sons, Inc., N.Y.

Meyer, M.W., R.D. Brown, and M.W. Graham. 1984. Protein and energy content of white-tailed deer diets in the Texas Coastal Bend. J. Wildl. Manage. 48:527-534.

Powell, J., and T.W. Box. 1966. Brush management influences preference values of south Texas woody species for deer and cattle. J. Range Manage. 19:212-214.

Rogers, L.L. 1987. Seasonal changes in defecation rates of free-ranging white-tailed deer. J. Wildl. Manage. 51:330-333.

Rollins, D., F.C. Bryant, D.D. Waid, and L.C. Bradley. 1988. Deer response to brush management in central Texas. Wildl. Soc. Bull. 16:277-284.

Sawyer, T.G., R.L. Marchinton, and W.M. Lentz. 1990. Defecation rates of female white-tailed deer in Georgia. Wildl. Soc. Bull. 18:16-18.

Scifres, C.J. 1980. Brush management-principles and practices for Texas and the Southwest. Texas A\&M Univ. Press, College Sta.

Scotter, G.W. 1980. Management of wild ungulate habitat in the western United States and Canada: a review. J. Range Manage. 33:16-28.

Severson, K.E., and A.L. Medina. 1983. Deer and elk habitat management in the Southwest. J. Range Manage. Monogr. 2, Soc. Range Manage. Denver, Colo.

Steel, R.G.D., and J.H. Torrie. 1980. Principles and procedures of statistics. 2nd ed. McGraw-Hill Book Co., Inc., N.Y.

Vallentine, J.F. 1980. Kange developments and improvements, 2nd ed. Brigham Young Univ. Press, Provo, Ut

Yoakum, J., W.P. Dasmann, H.R. Sanderson, C.M. Nixon, and H.S. Crawford. 1980. Habitat improvement techniques, p. 329-403. In: S.D. Schemnitz, ed. Wildlife management techniques, 4 th ed. The Wildl. Soc., Washington, D.C. 